\title{
Silence as an Uncertainty Communicational Inductor
}

\author{
Ştefan Vlăduţescu \\ University of Craiova, 13 A. I. Cuza Street, 200585, Craiova, Romania \\ E-mail address: stefan.vladutescu@yahoo.com
}

ABSTRACT

The study explores the silence as communicational element and as highlights its specificity as an inductor of uncertainty. Thesis that sile proved by using the comparative method and procedures of natural 1 fic and er comparison between word and silence follows some characteristic io f silence: element without accredited code (there is not a coherent an ( isablo de of sience); b) mostly silence is not only element of communication, but autonom message, the fact that peace is a property of nature and the silence is intentional human e ment; d) the fact $y$ at silence is no speech, logos, discourse, it is an incomplete and expressive "lar uage"; e) that silence is the most important communicational element and uncertainty message induc

Keywords: communication; uncertainty; silence

\section{INTRODUCTION}

What, before all, m a d ings the universe is not the word, is not the silence, is not the knowing. Man brings meaning the universe and gives a sense to the world. The fundamental human orld n envirenment of meanings. The first thing he perceives in the universe is noise an is bon to a huge and relentless noise. Matter is uncontrollably loud, boisterous ene gy is ncontrolla 1 e. The only key element in the universe, multi-verse, which in terms of e ir contr llable is information, is communication. S. Zizek considers that "The primordia et is no Silence (waiting to be broken by the divine word) but the noise, the contro murm $f$ neal in which there is not yet distinction between a figure and its ba roun . The firs creative act is therefore to create silence" (Zizek, 2006, p. 224). Silence is a However, people communicate through silence.

S. ce is a matter of non-verbal meaning. Silence is communication (Khan, 1963), is a strategic c munication element: "silence, as a non verbal communication, is a strategic way of communicating and a precise series of meanings refers to this modality" (Penna \& Mocci, 2005). Silence is an item without code and speaks in a infinity of codes. Look thrown silence stimulates language to speak gaze (Lis \& Bajdor, 2013; Craft \& Davis, 2013). Any question answering silence, like a mirror in question code. Significant speaking, silence is liquid: in the form of code that we think of it; and much more, it radiates multiple meanings: Silence is a multifaceted, yet generally unappreciated, component of human communication, both in meaning and function" (Damron \& Morman, 2009, p. 185) (also Nakane, 200; Fragouli \& Orlitsky, 2005; Dhulipala, Fragouli \& Orlitsky, 2010). Silence has communicative functions 
(Jensen, 1973; Bruneau \& Satoshi, 1988; Bilmes, 1994) and needs a pre-word to define the silence itself. Man silent installs.

Over a thousand years of language training, man has developed silence. Language and silence are two countries that are shaping stones each (Jaworski, 1997; Kenny, 2011). In a form or another, language appears whenever he comes with his specific silence. As demonstrated C. Kenny "Silence manifests in many forms (...). Cultural, religious, and sociological" (Kenny, 2011, p. 69). Between language and silence, we record (in writing civilization started in European culture and civilization of ancient Greek) a level separation: silence climbed status autonomous message, while the only remaining element-word message. A single word is not a message, a single silence is a message When e conversation stops and installs the silence, the Greek says, "Hermes is cros " (Verna 1995, p. 193).

\section{HERMES, SILENCE, CROSSING, MESSAGE}

Hermes is, in principle, the message god. Silence mean nes cross The message God brings the silence. On the other hand, the message d can an unknown message. When he goes, the speech is silent. As to be the silence arr terruptio f/he conversation so that the break to bring thought to gathering ideas int a message? Is H)-rmes crossing only to diversify the speech by a silence? Is bring it just the hessage of t'e conversation? Is carrying it the exact message we are? These questions do no ve, daily, an answer than themselves and the idea of being placed.

Hermes is always the carrier of a mes also Holgate, 201; Capurro, 2011). But Hermes is, also him, "bifrons": he brings a me sag and complementary, brings his own message or the message that is himcelf. That ermes carries two messages: the message to bring and the message in fact $0^{f}$ mes ger wh is recognized as messenger. As is built our world, it obliges the two mes : an explicit y.essage (message due) and a default message

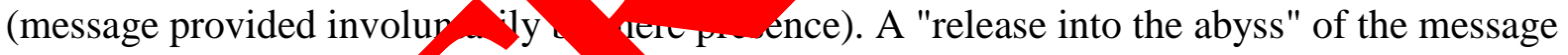
carried by Hermes is ey Hermes. rmes has more power than the message whose duty he brings. Those who eco the mes age, first receive Hermes. This receiving become expectation havin du notes signation. Always expected, yet never disappointing, Hermes is part of lived aestiny. The si Cexperience is a message of a Hermes who doesn't leave

This ce of ser antic download called Hermes is established as permanent expect One the messages of his crossing is silent. The message of not constant exic ence, he silen $1 \mathrm{~s}$ saturated of the Hermes crossing message. The Hermes crossing mes de discourse in silent. Hermes annihilates the speech estabinshes the possibility of the message. In fact, he mobilizes right the message that the p ility of a message is a message and not just message. The Hermes's crossing is, moreover, 2 frustration.

Always waited with joy that is frustrated by itself expectation consummation, once come Hermes brings something unexpected: the expectation is disappointed. The brought message is another message. Like any room leads into another room and would mean that the gap that separates them is at the remoteness limit of the away word, so thus a brought message will be, once known, a remote message. The known and the desired are part of two orders of different frustration. Hermes is always disappointing. By his crossing, the silence is 
impregnated with a message of which is not missing frustration and disappointment (Motoi, 2009; Georgescu, 2009).

Expected gladly, once come, he brings disappointment. Hermes brings the message that he himself is. Hermes is the message that he brings. What can be said about Hermes is about message. Aspired message coincides with the brought message. Hermes knows what message to bring. Aspired message is just the message brought by Hermes. The knowing of the message makes the message to not be anymore satisfactory. By knowing, the message loses its non-frustrating and ex-deceptive innocence. Even if we create the most beautiful messages, as soon as they were aware and once they came to us, they would not beanired messages anymore. And the perfect messages disappoint. In the silent of Hermes crossing gathered all the suffering that can acknowledge a message.

Silence is crossed by numerous passes. But not the crossing of Hermes arsects with the silence. The silence of his crossing is the repose that makes to $s^{t}$ ucture the ssare.

If the message always comes after, then the essence post fact of $t$ messa will involve also the silence. Hermes brings silence, but he doesn't co ry own and the carrier of silence is the speech. Regarding silence, Hermes is a powen He misses the silence as message when through its crossing, creates the a through in cross. The silence is not necessary to discharge him of the duty to w vide message. The message that Hermes brings is not the essence of Hermes: he is ou produc

Therefore, the crossing of Hermes store two messages one expected and disappointing, ultimately, and another unexpected al always gentle, generous, grateful of the other and open for reciprocity. The first messag the mess ge that Hermes brings. The second message is the default message of bis crossing. st is produced and transferred, i.e. explicitly, the second is suscitated and h on the silence fund. The crossing makes the silence to be explosive. The communi tio gration takes place by passing the implicit in explicit. The explicit masage bro ght by Hermes is accompanied by a default message generated by his crossing.

In speech or silence, $y$, the on who entrusting the messages makes them delayed. Hermes brings $p$ ag delayed, already.

The essence $g$ " $\mathrm{c}$-ing" of the message and the essence of "late-ive" of the philosophy is assf ia ed in message as in an ideal. Only existential message of essential purity is the phlosnphical mo age. Here Hermes is at his home, he may evolve in the plenitude of avai ilities: as propagator of verbal and taciturn messages. Hermes has no choice: he br expecte and disappointing message that can accomplish more than the silence

The lence lo o us to the man. In absence of being there is no silence, the more a pea no the silence is installed where is missing the spirit. It is constituted as a conce ant status of the human behind of not speaking. Through it is made visible the abstineno $r$ appears as an asceticism of the word, as an abstinence. Silence comes as a spiritual exercise. Silence is silent so as not to give away as silence. Trying not to say anything, it just says itself. The silence can be voluntary or involuntary. Its absolute, to that itself the word carries, calls for ignoring the intentionality. If it remained closed in lexeme, the silence would not exist. But it exists as a great effort, as a spiritual effort. 


\section{THE TIME OF SILENCE}

It is mentioned here the status of silence in the Pythagoras's school. Right from the start, young people who came to learn were examined after physiognomy. That one who was investigated by him and found capable, was immediately accepted for instruction and "it was prescribed a certain time of silence" (Dumitriu, 1974, p. 42). The silent one was listening to what others say; he was not allowed to ask if they do not sufficiently understand and also not to comment on what he had heard. The silence time does not take to anyone less than two years. Those who were on this road of silence and listening were called auditors. Onanthey learned the hardest things - silence and listening - they also start to become sch aarly h is kind of silence, then were allowed to speak, to ask, to write what they had he Pythago proceeds gradually in his philosophy. This philosophy contained indeed a ansing, mystagogy and a contemplation. Thus were removed false opinions an a prejudico Zeliss, 1955; Baker, 1961; Le Breton, 2001).

\section{THE PLACE AND THE SOURCE OF SILENCE}

The silence can come from three directions. It subst of the speech, or a form of the speech, or is the general fund from whict emerge the speech.

a) The thesis of the alternation silence - speech. Th cilence can be drawn from speech. The end of the speech establishes the inexpressible. it car action without words. The discourse gives up to action. The cogitative rit is hidito plotting. The silence comes as obligation or as project. The silence - obli gtto nlanning a revenge. The silent man is thinking for something. An inertness of the $\mathrm{m} r \mathrm{r}$, is $\mathrm{h}$ ard in silence. The obligation rests on a denial and promotes a redemptiy does $n$ want to give itself away. It lies in words and rinse in peace. This is the silen wha las one' evenge. A paid silence moves in waiting. It is released when it intervenes. of the words. It strikes yout jo, vithout gentleness and without condescension. Silenceobligation is silent unp ophical. $\mathrm{k}$ s of a lack of speech tension. Thus, is defined only as the interval betr en speecheo. A silence like this is just waiting to speech. The obligation to be ant denotes the background is the speech, and the silence is the relief. The rest is silf ice, so s Hamlet.

b) The thesis siler as a particular case of speech. E. Coşeiru retains the silence among elem of peech; his thesis is that speech is more comprehensive than the lang age, cause acludes also its own circumstances. Language does not possess this cio sta sol size $/ n$ addition, the speech includes also the nonverbal behaviors: behavior, gestur faciar expressions, including the silence (Coşeriu, 1988, p. 1). In contrast to the silence-o ation, which is also a voluntary silence, the silence-state is looming. It occurs as a statutory, peech event. The world order is represented by the silence, the speech comes as an uncontrolled surprise. In this case, the speech misses to be a particular case of silence. On a background of peace, tranquility, calm, rises a speech to make the connection between two silences. It is not neglected anything, because anyway everything falls into silence. The speech between two silences is a small bridge that falls easily. In such a silence situation, the words are required. No matter who says them because the opening is justified in the failure of the silence. The gold of the lack of the speech is not the gold of the absence of the words. Who is silent does not exist, but who is silent knows (Otovescu-Frăsie \& Motoi, 2010; 
Georgescu, 2010). The speech is a pause of the silence, it is not a riposte. The speech does not represent an answer, because between two speeches the distance is so great, that the idea of response is itself a form of silence. No answer to anyone. Each dies alone, said A. Huxley. Each speaks a previous silence and a subsequent silence. An inertness rises in every such of silence. A speaking stuffiness is built on silence. Now silence gives away in speech. Each speaks alone. The philosophical message intimates, insinuates, assumes that after speaking has to begin the cogitation.

In Anton Dumitriu's opinion (1984, p.7), originally, in ancient Greece, the goal of philosophy was "to achieve a certain state, a way of being". Gradually, this on has transformed, it was invested as a 'way of saying, but without losing the initial ide ar . Bea a way of saying, philosophy found himself face to face with the idea to not s to be sile, On this way, the silence took advantage and became philosophem. Beyond of th hilosopl discovery fact as antonym of telling philosophy there is something in th direction the re knowing brings the word that designates the action to say. "Talk " in eek is alled "legein". Following now A. Dumitriu, we must emphasize that the vo three Canings: 1) to fall asleep, to stay inactive, 2) to collect, 3) to speak. $M$ anings $n$ tha "a certain activity remains inactive, in that to collect can be reached th $\mathrm{s}_{\mathrm{h}} \mathrm{h}$, which ans that there is a sorting that the language makes to form verbal expres ons we have here the silent and the unseen"(1984, p. 106). The Greek word "to sp an les the s. C (Kociatkiewicz \& Kostera, 2003; Dimitris \& Vakola, 2007; Grabara, Kolcun \& Kot, 2014). We see that the silence can be language or cogitative.

c) The thesis of the silence as background of ch apr carance "We speak on the background of the silence" shows J.-P. Sa (2000, p. -1. In the side of our word is not another word. The silence is possible and a the movement of the discourse is in opposition. By silence the speech is canceled $T_{n} \mathrm{~m}, \mathrm{n}$ has two choices in life: the silence and the speech. His acts are perfo in pern inently stochastic request. From this point of view, the Sartre man is saved. artre ceriolog. as a simple logic: to be silent or to talk are equivalent. First requiremen a vis the awareness the spech arises from silence. If the back ound w not be possible as the silence, the speech would not be possible as speech (Sa $2000, \mathrm{p} . \lambda$ The silence does not generate speech, it just pushes it to the forefront. $\mathrm{C}$ y $\mathrm{h}$ ircumstances where there is a criterion of the silence can individualize a poch. Whe er the desideratum delimitation is ignored the speech has value of silen e, the ackgroung absorbs the figure. Saying that the silence is the background, Sartre empra st the ingu of the speech.

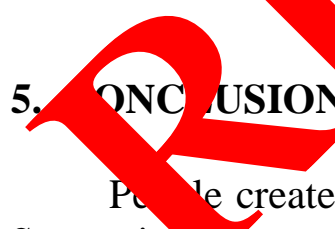

Some circ re meanings appear as silence. There is no rule of insertion of silence. There is no way to teach and/or learn silence. Although silence is one of the fundamental human experiences, for it does not exist yet accredited ontology and hermeneutics. Therefore, silence is an uncertainty communicative inductor.

\section{ACKNOWLEDGMENT}

This work was partially supported by the grant number 33C/2014, awarded in the internal grant competition of the University of Craiova. 


\section{References}

[1] R. Capurro (2011). Angeletics - A Message Theory. In R. Capurro \& J. Holgate (Eds.), Messages and Messengers: Angeletics as an Approach to the Phenomenology of Communication (pp. 5-15). Vol 5. ICIE Series: Munich, Germany.

[2] A. Borowski, International Letters of Social and Humanistic Sciences 11 (2014) 1-168.

[3] S. Zizek (2006). Burned by the sun. In S. Zizek (Ed.), Lacan: The Silent Partners (pp. 217-230). New York: Verso.

[4] S. Baker, Journal of General Psychology 53 (1955) 145-167.

[5] C. Fragouli, A. Orlitsky (2005). Silence is golden and time is money: power are communication for sensor networks. In Proceedings of Allerton Conf rence or Comm., Control and Computing.

[6] A. Borowski, International Letters of Social and Humanistic So en 4, 2013) 0/4.

[7] T. Lis, P. Bajdor (2013). Sales Logistics as a Model Used b Compant Tulfi ing Individual Customer's Needs. In: Challenges in Contem or Managem. Monograph. Scientific Editors Anna Lemańska-Majdrik Piotr ๆski, Sékcja Wydaw. WZP Częstochowa.

[8] J. C. H. Damron, M. T. Morman, Human Comm nication 14(3) (2009) 183-203.

[9] I. Grabara Naukowe Politechniki Częstochowski ar 153 El ktrotechnika z. 16 cz.1 (2001).

[10] A. K. Dhulipala, C. Fragouli, A. Orlitsk try theory, IEEE Transactions on 56(1) (2010) 350-366.

[11] Kinga Dziwańska, Internat ona. Ptters of Social and Humanistic Sciences 7 (2013) 96-112.

[12] I. Nakane, Multiling a-sourm of Cross-Cultural and Interlanguage Communication 24(1-2) (2005)

[13] M. P. Penna.S. Mocch 05). The systemic approach to the communicative silence. In Procee ings of the 6tm Cems Science European Congress, Paris, September 19-22.

[14] J. Bilp Semi smia 8 (1994) 73-87.

[15] T. Rruneau Satos 1, World Communication 17(1) (1988) 1-33.

[16 E. C eriu (19y ). Sprachkompetenz: Grundzuge der Theorie des Sprechens. Tubingen:

[17] B. vitris, M. Vakola, Athens university of economics and business (2007) 1-19.

[18] A. Dýmitriu (1974). Philosophia mirabilis. Bucureşti: Enciclopedică Română.

[19] A. Jaworski (Ed.). (1997). Silence: interdisciplinary perspectives (Vol. 10). Walter de Gruyter.

[20] C. Kenny (2011). The Power of Silence: Silent Communication in Daily Life. Karnac Books.

[21] M. M. Khan, Bulletin of the Menninger Clinic 27 (1963) 300.

[22] J. Kociatkiewicz, M. Kostera, Ephemera 4(3) (2003) 305-313. 
[23] D. Le Breton (2001). Despre tăcere. Bucureşti: Editura All.

[24] M. A. Zeligs, Journal of the American Psychoanalitic Association 9(1) (1961) 7-43.

[25] J. Holgate (2011). The Hermesian Paradigm: A mythological perspective on ICT based on Rafael Capurro's Angelitics and Vilem Flusser's Communicology. In R. Capurro \& J. Holgate (Eds.), Messages and Messengers: Angeletics as an Approach to the Phenomenology of Communication (pp. 58-89). Vol 5. ICIE Series: Munich, Germany.

[26] V.-A. Enăchescu (2013). Journal of Community Positive Practices, 13(2).

[27] Andrzej Borowski, International Letters of Social and Humanistic Scienc 2 (2014) 110-121.

[28] M. G. Mangra, E. A. Cotoc, A. Traistaru (2013). Sustainable Econ mic Develo Through Environmental Management Systems Implementation, rnal,

[29] B. M. Dascălu (2006). Germanitatea şi literele române. Bu aroşti: _ura Fu daţia Culturală Ideea Europeană.

[30] A. Borowski, International Letters of Social and Hun istic . vnces 312013) 69-74.

[31] Marin Drămnescu (2013). Postmodern Society g a Indıvidual Alt ation. Revista de PSIHOterapie Experienţială.

[32] Ştefan Vlăduţescu, International Letters of Soc and Hum nistic Sciences 10(2) (2014) 100-106.

[33] Iulian Bitoleanu, International Letters 161-121.

[34] Dumitru Vladut (1998). Fig arn actice, petitiv-adjunctive In stilul stiinfific romanesc din secolul al Ylea, ilologie.

[35] Sartre, J.-P. (2000). arsenţ adevar. Iaşi: Polirom.

[36] Ioan David (201\%). să şi cultu (Press and Culture). Timiţoara:David Print.

[37] A. Borowski Letters of Social and Humanistic Sciences 4 (2013) 70-74.

[38] J. Titten run, I, rnationa Letters of Social and Humanistic Sciences 2 (2014) 20-40.

[39] R. Bărbu, D. Ţâ , L. Țâţu (2007). Investment in human capital. EU integration o tuniti Rom nia within EU: opportunities, requirements and perspectives (pp. 0-435). Sibiu: Editura Universităţii Lucian Blaga.

[40] Internet and digital technology - influences on audiovisual co runication and on teaching at master's degree level, Valencia, 2012, Published by Inter conalAssociation of Technology, Education and Development -ISBN: 97884-615-5563-5

[41] Mihaela Gabriela Paun (2013). Changes in Management as an Instrument of Educational Intervention. European.

[42] A. Borowski, International Letters of Social and Humanistic Sciences 6 (2013) 86-90.

[43] M. Siminică, A. Traistaru (2013). Self-Directed Learning in Economic Education. International. 
[44] Donovan A. McFarlane, International Letters of Social and Humanistic Sciences 4 (2013) 35-44.

[45] Dan Ionescu, Cristina Pretorian, International Letters of Social and Humanistic Sciences 9 (2014) 49-56.

[46] Daniela Gîfu (2014). Temeliile Turnului Babel. O perspectivă integratoare asupra discursului public. Bucureşti: Editura Academiei Române.

[47] C. Otovescu-Frăsie, G. Motoi, Revista de Stiinte Politice 26 (2010).

[48] C. M. Georgescu, Revista de Stiinte Politice 36 (2012).

[49] Janusz Grabara, Michal Kolcun, Sebastian Kot (2014). The role of infory on system. in transport logistics. International.

[50] C. M. Georgescu, Revista de Ştiinţe Politice/Revue des sciences p litiqu 23 (2 67-78.

[51] Stefan Freytag, International Letters of Social and Humani rancien 10 (2 13) 25-31.

[52] G. Motoi, Revista de Stiinte Politice 28 (2010).

[53] Alexandra Iorgulescu, International Letters of S cial and Humany Ic Sciences 7 (2014) 14-21.

[54] S. Craft, C. N. Davis (2013). Principles of Ame an Journd ism: An Introduction. Routledge.

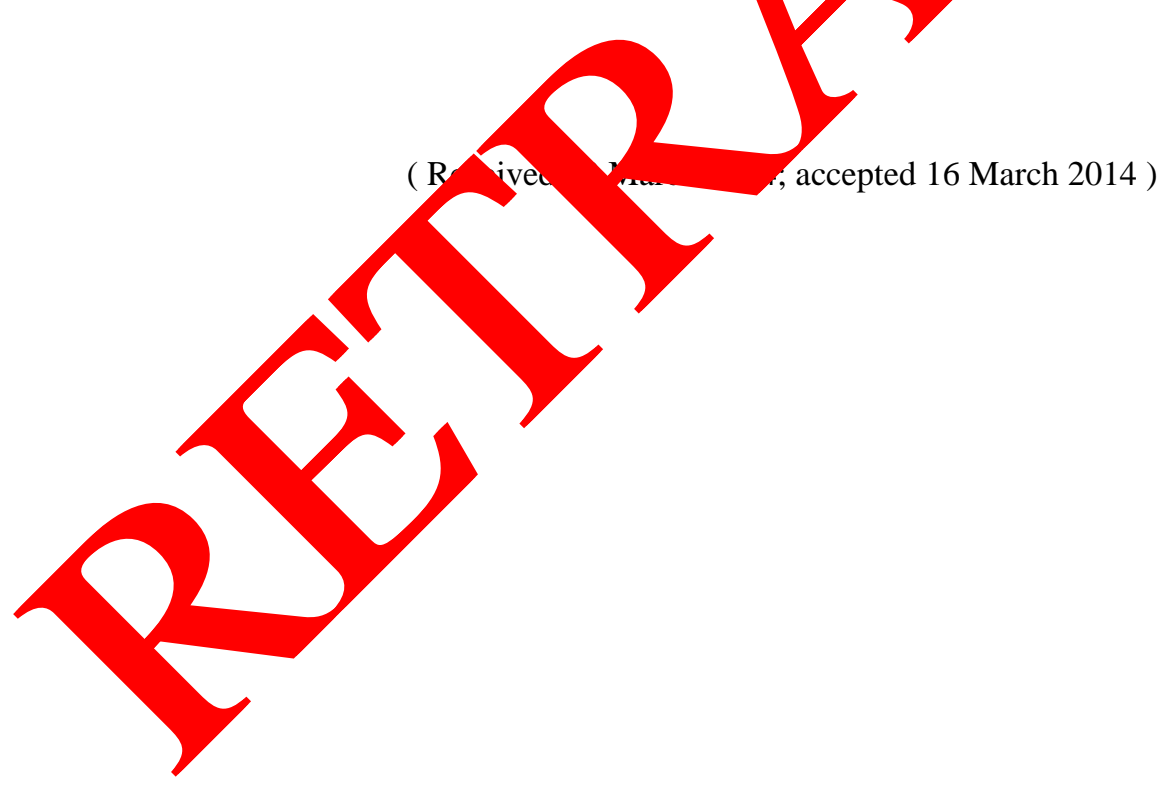

